\title{
Assessment of Indoor Radon Concentration in Residential Buildings at Ouagadougou and Estimation of the Annual Effective Dose
}

\author{
Bambara Telado Luc ${ }^{1}$, Kabore Karim ${ }^{2}$, Derra Moumouni ${ }^{3}$, Beogo Cedric ${ }^{4}$, \\ Ousmane Ibrahim Cisse ${ }^{5}$, Francois Zougmore ${ }^{5}$ \\ ${ }^{1}$ Physics and Chemical Department, Institute of Sciences, Ouagadougou, Burkina Faso \\ ${ }^{2}$ Physics Department, Virtual University, Ouagadougou, Burkina Faso \\ ${ }^{3}$ Physics Department, University Norbert Zongo, Koudougou, Burkina Faso \\ ${ }^{4}$ Physics Department, University Thomas Sankara, Ouagadougou, Burkina Faso \\ ${ }^{5}$ Physics Department, University Joseph KI-ZERBO, Ouagadougou, Burkina Faso \\ Email address: \\ telado.luc.bambara@gmail.com (B. T. Luc)
}

\section{To cite this article:}

Bambara Telado Luc, Kabore Karim, Derra Moumouni, Beogo Cedric, Ousmane Ibrahim Cisse, Francois Zougmore. Assessment of Indoor Radon Concentration in Residential Buildings at Ouagadougou and Estimation of the Annual Effective Dose, Burkina Faso. Radiation Science and Technology. Vol. 7, No. 2, 2021, pp. 41-46. doi: 10.11648/j.rst.20210702.14

Received: May 13, 2021; Accepted: June 4, 2021; Published: June 15, 2021

\begin{abstract}
The second most important cause of lung cancer after smoking is a radon gas. Thus, the determination of indoor radon concentrations in residential buildings is an important public health concern. The purpose of this research was to measure the concentration of radon gas in residential homes in the city of Ouagadougou and evaluate the annual effective dose, effective dose equivalent and the relative risk of lung cancer. The present study used the digital radon detector air things of cranium to determine the concentration of radon in twenty one homes at Ouagadougou. The digital radon detector air Things of corentium was placed in each residential building for a minimum period of one week and the concentration values are read every 24 hours. The values recorded are the short term average and the long term average. This study showed that the average radon concentration was $26.90 \pm 2.58 \mathrm{~Bq} / \mathrm{m}^{3}$ in residential homes at Ouagadougou. The average radon effective dose rate was calculated as $0.68 \mathrm{mSv}$ per year and the average effective dose equivalent of $1.63 \mathrm{mSv}$ per year. The average relative risk of lung cancer (RRLC) due to indoor exposure was 1.02. The concentration of radon in one house was found to be greater than $100 \mathrm{~Bq} / \mathrm{m}^{3}$, which is above the level allowed by the World Health Organization (WHO). The radon Effective Dose Equivalent in 14.3\% of homes were slightly larger than the limit of the recommended action level (3-10 mSv per year) as reported by the ICRP-1993. It seems necessary to increase the public's awareness of this issue and to take action to reduce radon in homes when the concentrations are above.
\end{abstract}

Keywords: Radon, Dose, Relative Risk, Residential Buildings

\section{Introduction}

Thorium and uranium are common naturally occurring elements found in varying amounts in rock and soil, they naturally decay releasing a radioactive gas, radon- 222 . Radon-222 decay into radioactive elements by emitting alpha particles, which can damage lung tissues.

Outside a building, the concentrations of radon in the air are diluted, and are lower than the indoor concentrations, which explains that radon presents a great risk in buildings. Radon can accumulate to significant levels in the indoor environment. The extent of the radon concentration indoors depends primarily on the construction of a building and the amount of radon in the underlying soil. The composition of the soil under and around a home affects radon levels and the ease with which radon migrates into a building.

However, the basic itinerary of potential human exposure to radon are radon gas by inhalation and by ingestion of radon dissolved in water. Radon in groundwater or in materials used in the construction of buildings are sources of human exposure. The radon inhaled into the lungs could easily be exhaled through the pulmonary circulation. When 
radon gas is inhaled, it can interact with biological tissue in the lungs leading to DNA damage which is considered an important step in the carcinogenic process [1].

In the USA, studies have shown that radon in homes causes 21,100 lung cancer deaths per year which makes it the second leading cause of lung cancer deaths [1]. The average radon concentration in homes in the UK is 21 becquerels per cubic meter $(\mathrm{Bq} / \mathrm{m} 3)$. Each year around 1,100 lung cancer deaths have been linked to radon in the home [2]. Studies in Canada have shown that the radon concentration in residential homes is higher than in school buildings, 4.7 times higher than in public buildings and indoor workplaces, and 12 times higher than in the open air. Exposure to radon in residential homes contributes to $90 \%$ of the risk of developing radon-induced lung cancer [3].

Several studies on radon in residential buildings around the world have been carried out. The study of Indoor Radon Levels in dwellings of Gezira state in Sudan shows that the radon concentrations varied from $57 \pm 8 \mathrm{~Bq} / \mathrm{m}^{3}$ to $41 \pm 9 \mathrm{~Bq} / \mathrm{m}^{3}$, with an average of $49 \pm 10 \mathrm{~Bq} / \mathrm{m}^{3}$. The minimum and the maximum annual effective dose rate in dwellings of Gezira state was 1.05 $\mathrm{mSv}$ per year and $1.43 \mathrm{mSv}$ per year, respectively. The relative lung cancer risk for radon exposure in dwellings of Gezira state was $1.044 \%$ [4]. Choukri et al., show that, the measured volumic activities of radon vary in houses, between 31 and $136 \mathrm{~Bq} / \mathrm{m}^{3}$ (0.55 and $2.39 \mathrm{mSv} /$ year) with an average value of $80 \mathrm{~Bq} / \mathrm{m}^{3}$ (1.41 mSv/year) in Morocco [5].

The radon concentrations and the annual effective dose in these houses varied from (38.62 to 120.39) Bq.m ${ }^{-3}$ and (0.96 to 3.06$) \mathrm{mSv} \mathrm{y}^{-1}$ respectively in Alexandria City, Egypt [6].

The annual average radon concentration in the dwellings was found to vary from 21 to $722 \mathrm{~Bq} \mathrm{~m}^{-3}$ with an average value of $107 \pm 75 \mathrm{~Bq} \mathrm{~m}^{-3}$ in the Province of Naples [7].

Hassanvand et al. (2019), show that the indoor radon concentration ranged from 1.01 to $206.53 \mathrm{~Bq} / \mathrm{m}^{3}$ with an average value of $55.19 \mathrm{~Bq} / \mathrm{m}^{3}$, and the average annual effective dose to the population in Aleshtar (western part of Iran) was estimated to be $1.39 \mathrm{mSv} / \mathrm{y}$ [8].

H. A. Yalım et. al. (2018), show that the measured values of radon gas at Workplaces of Afyonkarahisar Province varied from $13 \mathrm{~Bq} \cdot \mathrm{m}^{-3}$ to $1,932 \mathrm{~Bq} \cdot \mathrm{m}^{-3}$, and the calculated average values were in the range of $21.75 \mathrm{~Bq} \cdot \mathrm{m}^{-3}$ and $1,032.50$ Bq. $\mathrm{m}^{-3}$ [9].

The present study of radon in residential buildings constitutes an important public health issue which requires more information on concentrations. This study aims to contribute to the assessment of the radon concentration in residential buildings and their impact on the health of residents.

\section{Materials and Methods}

\subsection{Study Area}

Burkina Faso is located in the West Africa. Its area is 274,000 square kilometers. It shares its borders with 6 countries, namely Mali to the north and west, Niger to the north and east, Benin to the south-east, Ghana and Togo to the south, the Côte-d'Ivoire to the west and south.

The Ouagadougou is administrative capital of Burkina Faso $\left(1^{\circ} 28\right.$ to $1^{\circ} 36$ west longitude and $12^{\circ} 20$ to $12^{\circ} 26$ north latitude) and is situated in the center part of the country.

\subsection{Technical Means of Measurement}

For the measurement of radon in residential buildings, our choice fell on the digital radon detector AIR THINGS of CORENTIUM for its very high precision. For concentration measurements, the digital radon detector AIR THINGS of CORENTIUM was placed in each residential building for a minimum period of one week. The concentration values are read every 24 hours for one week. The values recorded are the short term average and the long term average.

The digital radon detector AIR THINGS of CORENTIUM gives two values on each reading, which are: short term average and long term average.

The "long term average" value displayed by AIR THINGS of CORENTIUM designates the average radon concentration for continuous measurement, one year maximum (recalculated once a day). The value "short term average" represents the average of the radon concentration of the last 24 hours ("1 day", recalculated every hour) and the average concentration of the last week ("7 days", recalculated once per hour).

Typically, the long-term average concentration is used to identify the health risks that radon poses. Short-term averages concentration are often used to identify the effects of actions taken to reduce the level of radon (example: modification of ventilation). Short-term concentration averages can also be used to obtain a general, but relevant, estimate of concentration levels, in cases where it is not possible to make a long-term measurement.

According to the recommendation of the World Health Organization (WHO), the annual average concentration of radon inside buildings should be less than $100 \mathrm{~Bq} / \mathrm{m}^{3}$.

Proposed measurement method: A building can be diagnosed by performing a short-term measurement (at least 7 days), in each of the rooms regularly frequented by its occupants. Subsequently, and in order to obtain a more precise result, it is advisable to carry out a long-term measurement (at least 2 months) in the room which obtained the highest level of radon.

After completing the radon measurements in the building, the RESET function located on the back of the digital radon detector to reset and erase the device data before starting a new measurement.

It is recommended to keep the instrument continuously ON.

\subsection{The Annual Effective Dose}

In this study, the annual effective due to indoor radon exposure was estimated using the radon concentration $\left(C_{R n}\right)$, the equilibrium factor $(\mathrm{F})$, the occupancy factor $(\mathrm{O})$, the number of hours in a year $(\mathrm{T})$ and the dose conversion factor $(\mathrm{D})$.

The following formula was used for annual effective dose calculation $[10,11]$ : 


$$
D(m S v)=C_{R n} \cdot F \cdot O \cdot T \cdot D
$$

Where, $\mathrm{C}_{\mathrm{Rn}}$ is in Bq. $\mathrm{m}^{-3}, \mathrm{~F}$ is taken to be $0.4, \mathrm{O}$ is estimated that people spends $80 \%$ of their time indoor, $\mathrm{T}=24$ hours $\mathrm{x}$ 365 days $=8760$ h. $\mathrm{y}^{-1}$, and D converts radon concentration into effective dose, $9 \mathrm{nSv}\left(\mathrm{Bq} \cdot \mathrm{m}^{-3} \cdot \mathrm{h}^{-1}\right)$ [12-17].

\subsection{Effective Dose Equivalent}

The radiation produced by radon is alpha particle and the critical tissue expose by radon for lung tissue. The calculation of effective dose equivalent was done using weighting factors for alpha particle for lung tissue were based on ICRP, 2007. The weighting factor for alpha particle is 20 and the weighting factor for lung tissue is $0.12[12-14,19]$.

Equivalent dose is the dose received by occupants. The effective dose equivalent was calculated by using annual exposure dose $\mathrm{D}$ in $\mathrm{mSv}$, weighting factors for alpha particle $\left(\mathrm{w}_{\mathrm{R}}\right)$ and for lung tissue $\left(\mathrm{W}_{\mathrm{T}}\right)$.

The effective dose equivalent was estimated by the following formula [18]:

$$
E\left(m S v \cdot y^{-1}\right)=D \cdot W_{R} \cdot W_{T}
$$

\subsection{The Relative Risk of Lung Cancer}

The impact of radon indoor exposure on the health of residents was quantified by the relative risk of lung cancer $(R R L C)$ given by the following equation [20]:

$$
R R L C=\exp \left(0.00087352 \mathrm{C}_{\mathrm{Rn}}\right)
$$

\section{Results and Discussions}

\subsection{Radon Short Term and Long Term Average Concentration}

The reference level proposed by WHO to minimize health risks from radon exposure in buildings is $100 \mathrm{~Bq} / \mathrm{m}^{3}$. According to recent calculations by the International Commission on Radiation Protection, the reference level chosen by each country must not exceed $10 \mathrm{mSv}$, which corresponds to $300 \mathrm{~Bq} / \mathrm{m}^{3}[21,22]$.

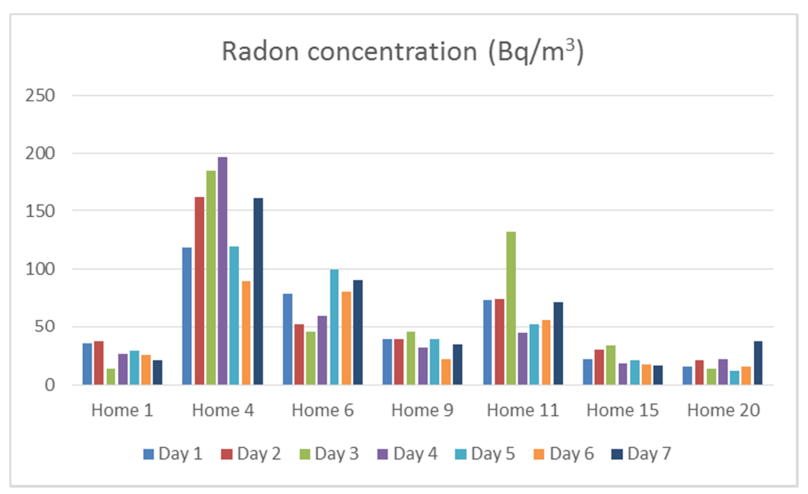

Figure 1. Variation of short term average concentration in some room.

The figure 1 and figure 2 show the short term average concentration and long term average concentration in some homes respectively.

The short term average concentration in homes 1, 6, 9, 15 and 20 were less than $100 \mathrm{~Bq} / \mathrm{m}^{3}$. All studies homes except home 4 , the short term average concentration were than the reference level set by WHO. In home 4, the short term average concentration varied from 89 to $197 \mathrm{~Bq} / \mathrm{m}^{3}$ during the seven day of measurement. The average concentration of day 2, 3, 4 and 7 were high than $150 \mathrm{~Bq} / \mathrm{m}^{3}$. In this home, we need to increased ventilation.

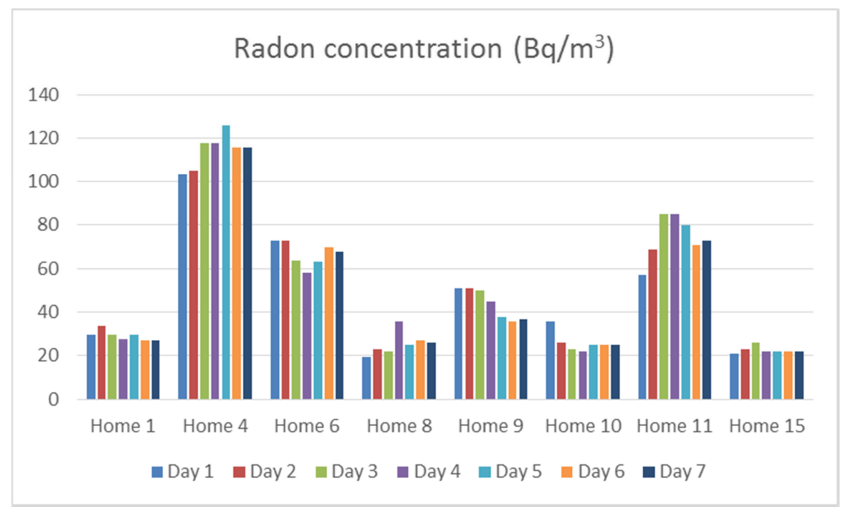

Figure 2. Variation of long term average concentration in some homes.

In homes $1,6,8,9,10,11$ and 15 , the long term average concentration were less than $100 \mathrm{~Bq} / \mathrm{m}^{3}$. In home 4 , the long term average concentration varied from 103 to $126 \mathrm{~Bq} / \mathrm{m}^{3}$ during the seven day of measurement. The average concentration during the seven days of measurement were high than $100 \mathrm{~Bq} / \mathrm{m}^{3}$, this home represents a potential health hazards.

\subsection{Radon Long Term Average Concentration}

Table 1 shows the long term average concentration, the Standart Deviation, Maximun and minimum values of concentration in twenty one studies homes at Ouagadougou.

Table 1. Long term average concentration in studies homes.

\begin{tabular}{lllll}
\hline Location & Average & Standart Deviation & Maximun & Minimum \\
\hline H 1 & 29,43 & 1,80 & 34 & 27 \\
H 2 & 14,57 & 1,22 & 16 & 13 \\
H 3 & 8,71 & 1,18 & 10 & 7 \\
H 4 & 114,57 & 6,04 & 126 & 103 \\
H 5 & 12,43 & 1,22 & 14 & 11 \\
H 6 & 67,00 & 4,57 & 73 & 58 \\
H 7 & 13,29 & 2,33 & 16 & 10 \\
H 8 & 25,43 & 3,63 & 36 & 19 \\
H 9 & 44,00 & 6,00 & 51 & 36 \\
H 10 & 26,00 & 2,86 & 36 & 22 \\
H 11 & 74,29 & 7,76 & 85 & 57 \\
H 12 & 20,86 & 2,41 & 25 & 17 \\
H 13 & 19,43 & 1,88 & 26 & 17 \\
H 14 & 4,29 & 1,67 & 6 & 0 \\
H 15 & 22,57 & 1,10 & 26 & 21 \\
H 16 & 8,57 & 1,84 & 15 & 7 \\
H 17 & 7,86 & 0,73 & 10 & 7 \\
H 18 & 10,86 & 1,63 & 15 & 8 \\
H 19 & 13,71 & 2,04 & 17 & 10 \\
H 20 & 10,29 & 1,10 & 12 & 8 \\
H 21 & 16,71 & 1,10 & 20 & 15 \\
\hline
\end{tabular}


Table 2 shows the radon concentration Guidelines for Residential Homes set by Health Canada, World Health Organization, International Commission on Radiological Protection, United States Environmental Protection Agency and European Union.

Table 2. Radon concentration Guidelines for Residential Homes [22].

\begin{tabular}{ll}
\hline Organization & $\begin{array}{l}\text { Residential Level } \\
\left(\mathbf{B q} / \mathbf{m}^{\mathbf{3}}\right)\end{array}$ \\
\hline Health Canada & 200 \\
World Health Organization & $100-300$ \\
International Commission on Radiological Protection & 300 \\
United States Environmental Protection Agency & 150 \\
European Union & 200 \\
\hline
\end{tabular}

Radon measurements were completed in a total of twenty one homes. None of the twenty one homes surveyed had radon concentrations exceeding the $200 \mathrm{~Bq} / \mathrm{m}^{3}$ national Reference Level of Canada and European Union reference level (table 2). But the home 4, had the long term average concentration between, $100-300 \mathrm{~Bq} / \mathrm{m}^{3}$, the Residential Level of World Health Organization. The maximum concentration measured was $197 \mathrm{~Bq} / \mathrm{m}^{3}$ in a home 4, which was in a defined higher risk area.

\subsection{Effective Dose Rate Indoors, Effective Dose Equivalent and Relative Risk of Lung Cancer}

Table 3 gives the calculated values of effective dose rate indoors, effective Dose Equivalent and relative risk of lung cancer in twenty one studies homes at Ouagadougou.

Table 3. Effective dose rate indoors, Effective Dose Equivalent and relative risk of lung cancer in studies homes.

\begin{tabular}{|c|c|c|c|c|}
\hline Location & Average & Effective dose rate indoors $\left(\mathrm{mSv}^{\left.-y^{-1}\right)}\right.$ & Effective Dose Equivalent & Relative Risk of Lung Cancer (RRLC) \\
\hline H 1 & 29,429 & 0,743 & 1,783 & 1,026 \\
\hline H 2 & 14,571 & 0,368 & 0,883 & 1,013 \\
\hline H 3 & 8,714 & 0,220 & 0,528 & 1,008 \\
\hline $\mathrm{H} 4$ & 114,571 & 2,892 & 6,942 & 1,105 \\
\hline H 5 & 12,429 & 0,314 & 0,753 & 1,011 \\
\hline H 6 & 67,000 & 1,691 & 4,060 & 1,060 \\
\hline H 7 & 13,286 & 0,335 & 0,805 & 1,012 \\
\hline H 9 & 44,000 & 1,111 & 2,666 & 1,039 \\
\hline H 10 & 26,000 & 0,656 & 1,575 & 1,023 \\
\hline H 11 & 74,286 & 1,875 & 4,501 & 1,067 \\
\hline H 12 & 20,857 & 0,527 & 1,264 & 1,018 \\
\hline H 13 & 19,429 & 0,490 & 1,177 & 1,017 \\
\hline H 14 & 4,286 & 0,108 & 0,260 & 1,004 \\
\hline H 15 & 22,571 & 0,570 & 1,368 & 1,020 \\
\hline H 17 & 7,857 & 0,198 & 0,476 & 1,007 \\
\hline H 18 & 10,857 & 0,274 & 0,658 & 1,010 \\
\hline Н 19 & 13,714 & 0,346 & 0,831 & 1,012 \\
\hline Н 20 & 10,286 & 0,260 & 0,623 & 1,009 \\
\hline Н 21 & 16,714 & 0,422 & 1,013 & 1,015 \\
\hline
\end{tabular}

The range of the radon effective dose rate varied from $0.108 \mathrm{mSv}$ per year to $2.892 \mathrm{mSv}$ per year. The average radon effective dose rate was calculated as $0.68 \mathrm{mSv}$ per year. The effective dose is slightly lower than the "normal" back ground level of $1.1 \mathrm{mSv}$ per year; as quoted by UNSCEAR-2000 [10, 11].

The radon effective dose rate in home 4 (2.892 $\mathrm{mSv}$ per year), home 6 (1.691 mSv per year), home 9 (1.111 mSv per year) and home 11 (1.875 $\mathrm{mSv}$ per year) were slightly larger than the "normal" back ground level of $1.1 \mathrm{mSv}$ per year; as quoted by UNSCEAR-2000 [10, 11], but way below even the lower limit of the recommended action level (3-10 $\mathrm{mSv}$ per year) as reported by the ICRP-1993 [23].

The range of the radon Effective Dose Equivalent varied from $0.260 \mathrm{mSv}$ per year to $6.942 \mathrm{mSv}$ per year, with the average Effective Dose Equivalent of $1.63 \mathrm{mSv}$ per year. The average value was high than the global average dose from inhalation of radon from all sources $(1 \mathrm{mSv} / \mathrm{y})$. The radon Effective Dose Equivalent in home 4 (6.942 $\mathrm{mSv}$ per year), home 6 (4.060 mSv per year), and home 11 (4.501 $\mathrm{mSv}$ per year) were slightly larger than the limit of the recommended action level (3-10 $\mathrm{mSv}$ per year) as reported by the ICRP1993 [23].

The RRLC range was from 1.004 to 1.105 with an average of 1.02 is almost negligible.

\subsection{Comparison}

Table 4. Comparison of radon concentration with others studies [20].

\begin{tabular}{ll}
\hline Country & Mean concentation \\
\hline USA & 46 \\
Demark & 53 \\
Brazil & 82 \\
Italy & 52 \\
Jordan & 32,4 \\
Saudi Arabia & 36,2 \\
Iraq & 75,1 \\
India & 30,3 \\
Pakistan & 138 \\
Sudan (Kordufan) & 109,43 \\
Sudan (Wad Almahi) & 41,52 \\
This Study & $26.90 \pm 2.58$ \\
\hline
\end{tabular}

Table 4 show the comparison of results with other results 
in various locations in the world. The mean concentration determined in the twenty one homes at Ouagadougou was less than the results in various locations in the world (USA, Demark, Iraq, Brazil, Italy, Jordan, Saudi Arabia, India, Pakistan and Sudan) [20].

\section{Conclusion}

The present study was designed to evaluate the radon concentrations in twenty one residential buildings at Ouagadougou, Burkina Faso. The results of this study indicated that the long term average concentration were less than $100 \mathrm{~Bq} / \mathrm{m}^{3}$ in most of studies homes. But the long term average concentration in one of studies homes varied from 103 to $126 \mathrm{~Bq} / \mathrm{m}^{3}$ during the seven day of measurement. The healthcare authorities should consider indoor radon gas as an important environmental risk factor in Ouagadougou because the radon Effective Dose Equivalent in $14.3 \%$ of homes were slightly larger than the limit of the recommended action level (3-10 $\mathrm{mSv}$ per year) as reported by the ICRP-1993.

Therefore, it is needed to reduce human exposure to this risk factor in sensitive areas through various methods.

\section{References}

[1] Hamzeh Al Zabadi, Samar Musmar, Shaza Issa, Nidal Dwaikat and Ghassan Saffarini, 2012. Exposure assessment of radon in the drinking water supplies: a descriptive study in Palestine. BMC Research Notes 2012 5: 29.

[2] Gray A, Read S, McGale P, 2009. Lung cancer deaths from indoor radon and the cost effectiveness and potential of policies to reduce them. British Med J 2009, 338: a3110.

[3] Jing Chen, 2018. Risk assessment for radon exposure in various indoor environments. Radiation Protection Bureau, Health Canada, 775 Brookfield Road, Ottawa, K1A 1C1 Ontario, Canada, December 2018.

[4] Elzain A.: A Study of Indoor Radon Levels and Radon Effective Dose in dwellings of some cities of gezira state in sudan. Nuclear Technology \& Radiation Protection: Year 2014, Vol. 29, No. 4, pp. 307-312.

[5] Choukri A., O.-K. Hakam, Equivalent doses of indoor 222Rn in some dwellings and workspaces in Morocco.

[6] Abd El-Zaher M. Abd El-Zaher, N. M. Fahmi, 2008. Studying the Variation of Radon Level in Some Houses in Alexandria City, Egypt. IX Radiation Physics \& Protection Conference, 15-19 November 2008, Nasr City - Cairo, Egypt.

[7] M. Quarto, M. Pugliese, F. Loffredo, V. Roca, 2016. Indoor radon concentration and gamma dose rate in dwellings of the Province of Naples, South Italy, and estimation of the effective dose to the inhabitants. Radioprotection 51 (1), 3136 (2016).

[8] H. Hassanvand, M. Birjandi, A. Amiri, M. S. Hassanvand, B. Kamarehie, 2019. Investigation of indoor radon concentration in dwellings of Aleshtar (western part of Iran) and estimation of the annual effective dose from exposure to radon. Volume 17, No 4 International Journal of Radiation Research, October 2019.
[9] H. A. Yalım, A. Gümüş and R. Ünal, 2018. "Determination of Indoor Radon Concentration and Effective Dose Equivalent at Workplaces of Afyonkarahisar Province", Süleyman Demirel Üniversitesi Fen Edebiyat Fakültesi Fen Dergisi, 13 (2), 29$35,2018$.

[10] UNSCEAR, 2000. Exposure of the public and workers from various sources of radiation, ANNEX B, 2008, pp. 223-293.

[11] United Nations Scientific Committee on the Effects of Atomic Radiation (UNSCEAR), 2000. Sources and Effects of Ionizing Radiation, Vol. I Annex A: Dose Assessment Methodologies, New York, 2000.

[12] Norafatin Khalid, Amran Ab Majid, Redzuwan Yahaya and Muhammad Samudi Yasir, 2014. Radiological Risk Assessment of Environmental Radon. The 2013 UKM FST Postgraduate Colloquium, AIP Conf. Proc. 1571, 169-176 (2014); doi: 10.1063/1.4858649 (C) 2014 AIP Publishing LLC 978-0-7354-1199-9/\$30.00.

[13] Hüseyin Ali YALIM, Ayla GÜMÜS, Rıdvan ÜNAL, 2018. Determination of Indoor Radon Concentration and Effective Dose Equivalent at Workplaces of Afyonkarahisar Province. Süleyman Demirel Üniversitesi Fen Edebiyat Fakültesi Fen Dergisi Süleyman Demirel University Faculty of Arts and Sciences Journal of Science 2018, 13 (2): 29-35 DOI: $10.29233 /$ sdufeffd. 442298 .

[14] Abdalsattar Kareem Hashim, Eman Ibrahim Awad and Hamza A. Mezher, 2017. Measurement of annual effective dose for Radon in Kerbala University Campus, Freiha, Iraq. Iraqi Journal of Public Health (2017), DOI 10.22317/ijph.03201705.

[15] Akeel T. Al-Kazwini, Mohannad M. Al-Arnaout, and Tiba R. Abdulkareem, 2020. Radon-222 Exposure and Dose Concentration Levels in Jordanian Dwellings. Hindawi Journal of Environmental and Public Health Volume 2020, Article ID 6668488, 7 pages, https://doi.org/10.1155/2020/6668488.

[16] Maryam Yarahmadi, Abbas Shahsavani, Mohammad Hassan Mahmoudian, Narges Shamsedini, Noushin Rastkari, Majid Kermani, 2016. Estimation of the residential radon levels and the annual effective dose in dwellings of Shiraz, Iran, in 2015. Electronic Physician (ISSN: 2008-5842), June 2016, Volume: 8, Issue: 6, Pages: 2497-2505, DOI: http://dx.doi.org/10.19082/2497.

[17] Mirsina Mousavi Aghdam, Stefania DaPelo, Valentina Dentoni, Viviana Fanti, Alessandra Bernardini, Paolo Randaccio, Daniele Chiriu, 2019. Measurements of Indoor Radon Levels and Gamma Dose Rates. Proceedings of the 5th World Congress on New Technologies (NewTech'19) Lisbon, Portugal - August, 2019 Paper No. ICEPR 149 DOI: 10.11159/icepr19.149.

[18] ICRP, The 2007 Recommendations of the International Commission on radiological Protection. ICRP Publication 103. Ann. ICRP 37, 2007. pp. 2-4.

[19] Amin S. A., S. D. Alalgawi and H. M. Hashimn, 2015.Indoor radon concentrations and effective dose estimation in AlKarkh side of Baghdad dwellings. IJST (2015) 39A4: 491495, Iranian Journal of Science \& Technology http://ijsts.shirazu.ac.ir.

[20] Abd-Elmoniem Ahmed ELZAIN, 2014. A STUDY OF IN DOOR RA DON LEV ELS AND RADON EFFECTIVE DOSE IN DWELLINGS OF SOME CITIES OF GEZIRA STATE IN SUDAN. Nuclear Technology \& Radiation Protection: Year 2014, Vol. 29, No. 4, pp. 307-312. 
[21] International Commission on Radiological Protection. International Commission on Radiological Protection Statement on Radon. (2009). ICRP Ref 00/902/09. Retrieved September 30, 2010, from http://www.icrp.org/docs/ICRP Statement on Radon(Novem ber_2009).pdf.

[22] Canadian Nuclear Safety Commission (CNSC), 2011. Radon and Health. Minister of Public Works and Government Services Canada 2011 Catalogue number CC172-67/2011-
PDF ISBN 978-1-100- 17765-6 Published by the Canadian Nuclear Safety Commission (CNSC) Catalogue number: INFO-0813.

[23] Protection Against Radon at Home and Work, International Commission on Radiological Protection, ICRP Publication 65 Ann, ICRP 23, 1993. 